\title{
PENGEMBANGAN MODUL BERBASIS QUANTUM LEARNING TEMA EKOSISTEM UNTUK KELAS V SEKOLAH DASAR
}

\author{
Amara Sasmita $^{1}$, dan Khusnul Fajriyah ${ }^{2}$ \\ Universitas PGRI Semarang
}

\section{Info Artikel}

Sejarah Artikel:

Diterima: 3 April 2018

Direvisi : 7 Mei 2018

Dipublikasikan: Jun 2018

\section{Keywords:}

Thematic Module,

Quantum Learning,

Ecosystem

\begin{abstract}
Putpose this research is produce Quantum Learning Module theme 5 appropriate ecosystems to be used as supporter of teaching materials of class $V$ SDN Lamper Tengah 02 Semarang. This research is a research development (Research and Development). The subjects of this study are 12 students from 42 class $V$. Data collected in this study are expert data module and expert material data and initial field trial results. The instrument of collecting data is questionnaire of interview with teacher and observation of school environment in 3 elementary schools, that is SDN Lamper Tengah 01, SDN Lamper Tengah 02, SDN Jomblang 01. Data obtained from questionnaire are analyzed descriptively. The development result is Quantum Learning based thematic module. Data processing is taken from media validation and metrics, and student response questionnaires.

Experimental validation of learning modules by $94.3 \%$, material expert validation $82.7 \%$ and $81.5 \%$ students responsiveness, it shows that the Quantum Learning based thematic module has been successful in the development of this resource is also worthy of use for being a learning thing which is interesting and fun. Suggestions that can be conveyed author is expected that teachers do not use only one resource only. At least, teachers use other teaching material support to support the main teaching materials. Learning facilities available in the library are printed lesson materials (textbooks) that are less relevant to the curriculum updated, added and more varied by adjusting the curriculum.
\end{abstract}

\begin{abstract}
Abstrak
Tujuan penelitian ini yaitu menghasilkan Modul berbasis Quantum Learning tema 5 ekosistem yang layak untuk digunakan sebagai penunjang bahan ajar siswa kelas V Sekolah Dasar Negeri Lamper Tengah 02 Semarang. Penelitian ini merupakan penelitian pengembangan (Research and Development) Subjek penelitian ini adalah 12 siswa dari 42 kelas V. Data yang dikumpulkan dalam penelitian ini adalah data ahli modul dan data ahli materi dan hasil uji coba lapangan awal. Instrumen pengumpulan data berupa angket wawancara dengan guru dan observasi lingkungan sekolah di 3 Sekolah Dasar, yaitu Sekolah Dasar Negeri Lamper Tengah 01, Sekolah Dasar Negeri Lamper Tengah 02, Sekolah Dasar Negeri Jomblang 01. Data yang di peroleh dari angket dianalisis secara deskriptif. Hasil pengembangan berupa modul tematik berbasis Quantum Learning.

Hasil validasi ahli modul pembelajaran sebesar 94,3\%, validasi ahli materi $82,7 \%$ dan tangggapan siswa $81,5 \%$, hal ini menunjukan bahwa modul tematik berbasis Quantum Learning telah berhasil dalam pengembangan bahan ajar ini juga layak digunakan karena menjadi suatu pembelajaran hal yang menarik dan menyenangkan. Saran yang dapat penulis sampaikan adalah diharapkan guru tidak hanya menggunakan satu bahan ajar saja. Setidaknya, guru menggunakan penunjang bahan ajar lainnya untuk menunjang bahan ajar utama. Fasilitas pembelajaran yang ada di perpustakaan yakni bahan ajar cetak (buku pelajaran) yang kurang relevan dengan kurikulum diperbaharui, ditambah dan lebih divariasikan dengan menyesuaikan kurikulum.
\end{abstract}

(C) 2018 Universitas Muria Kudus

\footnotetext{
Alamat korespondensi:

Program Studi Pendidikan Guru Sekolah Dasar

Fakultas Keguruan dan Ilmu Pendidikan Universitas Muria Kudus

Kampus UMK Gondangmanis, Bae Kudus Gd. L. 1t I PO. BOX 53

Kudus

Tlp (0291) 438229 ex.147 Fax. (0291) 437198

E-mail: amarasasmita@gmail.com
}

p-ISSN 2087-9385

e-ISSN 2528-696X 


\section{PENDAHULUAN}

Pendidikan di Indonesia mengalami ketertinggalan sehingga perlu terus-menerus berbenah. Hasil Penelitian yang dirilis oleh TIMSS (Trends International in Mathematics and Science Study) menunjukkan bahwa literasi Sains kita berada diurutan ke 35 dari 49 negara dengan pencapaian skor 433 dan masih dibawah ratarata internasional yaitu 500. Penelitian lainnya yang dilakukan oleh Organization Economic Cooperation and Development (OECD) yang bernama The Programme for International Student Assessment (PISA) tahun 2007, dalam literasi sains siswa Indonesia berada peringkat 50 dari 57 negara dengan pencapaian skor 393 (Novitasari, Masykuri, dan Aminah 2016). Padahal, persaingan di era global menuntut adanya sumber daya manusia yang unggul. Guru yang cerdas dan kreatif akan menjadi motivasi tersendiri bagi siswanya mau melaksanakan proses belajar dengan penuh semangat. Guru hanya perlu menyediakan alat media atau peraga sebagai model konkrit pendalaman materi untuk siswa (Hidayatama 2016).

Pada Hakikatnya kurikulum 2013 merupakan sebuah pembelajaran yang menekankan pada aspek afektif saja, tetapi juga aspek kompetensi yang berimbang antara sikap, keterampilan, dan pengetahuan, di samping cara pembelajarannya yang holistik dan menyenangkan. Zahira dan Filia (2017) menyebut bahwa tujuan kebijakan implementasi kurikulum 2013 adalah merujuk pada manusia yang dipersiapkan untuk memiliki kemampuan hidup yang kreatif, aktif, dan inovatif. Untuk dapat membentuk sumber daya manusia yang demikian haruslah dilakukan pembelajaran yang luas dan berikait erat dengan kehidupan peserta didik. Hajar (2013: 8) berpendapat kurikulum tematik adalah sebuah sistem pembelajaran yang tidak berpatokan pada mata pelajaran.

Hal senada juga di kemukakan oleh Muryanti (dalam Hajar 2013: 21) yang berpendapat bahwa kurikulum tematik adalah kurikulum yang memuat konsep pembelajaran sehingga dapat memberikan pengalaman bermakna kepada para peserta didik. Dengan demikian, jika seorang guru mengadakan proses pembelajaran dengan dilandasi kurikulum tematik, maka sebenarnya guru tersebut telah menyediakan keluasan dan kedalaman implementasi kurikulum secara konstekstual. Sehingga, proses pembelajaran sesuai dengan kebutuhan dan karakteristik peserta didik.Proses pembelajaran dalam model pembelajaran tematik diartikan sebagai proses interaksi antara peserta didik dengan peserta didik, antara peserta didik dengan sumber belajar, serta antara peserta didik dengan pendidik. Dalam model pembelajaran ini pula, proses pembelajaran lebih ditekankan pada keterlibatan peserta didik secara aktif. Di samping itu, proses pembelajaran tematik lebih berorientasi pada penerapan konsep belajar sambil melakukan (learning by doing). Melalui pembelajaran tematik integratif, peserta didik dapat mencapai keseimbangan antara soft skills dan hard skills yang meliputi aspek kompetensi spiritual, sosial, pengetahuan dan keterampilan.

Pembelajaran tematik perlu memanfaatkan sumber belajar, baik yang sifatnya didesain secara khusus untuk keperluan pelaksanaan pembelajaran maupun sumber yang tersedia di lingkungan yang dapat dimanfaatkan (Trimantoto 2016). Hal demikian juga dikemukakan oleh Nugraha (2017) bahwa terdapat unsur-unsur yang menentukan kualitas pembelajaran antara lain adalah sumber belajar (Nugraha 2017). Menurut Siswoyo, Ana (2016) pembelajaran tematik merupakan salah satu model dari pembelajaran terpadu. Kurikulum terpadu merupakan kurikulum yang memadukan beberapa mata pelajaran ke dalam objek aktif, yaitu dunia nyata siswa dalam satu aktivitas.

Asrori, Setyo Budi dan Triyono (2012) berpendapat bahwa aktivitas belajar merupakan salah satu bagian dalam proses pembelajaran, karena dengan aktivitas belajar maka siswa akan mendapatkan pengalaman baru dalam belajarnya. Aktivitas belajar tersebut terlihat dari kegiatan fisik maupun mental yang dapat diarahkan salah satunya melalui bahan ajar. Keberhasilan suatu pembelajaran tentunya tidak hanya dipengaruhi oleh guru saja, melainkan bahan ajar yang digunakan guru (Ningrum dkk 2017). Dengan pembelajaran tematik anak didik diharapkan mendapatkan hasil belajar yang optimal dan maksimal dan menghindari kegagalan pembelajaran yang masih banyak terjadi (Mandacahyanti 2016).

Namun, pada realitanya penerapan model pembelajaran tematik di sekolah-sekolah belum sesuai dengan yang diharapkan. Beberapa permasalahan adalah guru dan siswa hanya menggunakan bahan ajar yang disediakan oleh sekolah, seperti buku pegangan tematik dan buku LKS. Padahal pembelajaran tematik menuntut adanya pemanfaatan berbagai sumber, media, dan bahan ajar yang bervariasi untuk mendukung proses pembelajaran. Kendala lain juga dialami siswa yakni dalam mempelajari buku pelajaran (buku pegangan siswa dan LKS) 
siswa merasa kesulitan karena materi yang ada dalam buku utama sulit dipahami.

Kondisi yang dipaparkan di atas tidak jauh berbeda dengan kondisi pelaksanaan pembelajaran tematik di SD Negeri Lamper Tengah 02 Semarang. Berdasarkan hasil penelitian awal yang diperoleh melalui wawancara dengan guru kelas $\mathrm{V}$, ternyata guru mengalami kesulitan dalam menyesuaikan diri terhadap materi pelajaran yang terdapat dalam buku pegangan. Guru menilai bahwa muatan pembelajaran dalam buku pegangan terlalu banyak dan cukup berat untuk diselesaikan dalam kurun waktu yang telah ditargetkan. Dari aspek pemanfaatan bahan ajar, guru dan siswa hanya menggunakan buku pegangan (buku guru, buku siswa, LKS) sebagai bahan ajar satusatunya. Tidak tersedianya penunjang bahan ajar untuk siswa menyebabkan wawasan dan pengetahuan siswa tentang materi hanya sebatas pengetahuan yang terdapat di buku pegangan. Padahal, siswa dituntut memiliki kemampuan belajar yang lebih, baik dalam aspek inteligensi maupun kreatifitas.

Penggunaan model pembelajaran quantum dirasa mampu sebagai salah satu alternatif pembaharuan pembelajaran, karena menyajikan petunjuk praktis dan spesifik untuk menciptakan lingkungan belajar yang efektif, bagaimana guru merancang pembelajaran, menyampaikan bahan pembelajaran, dan bagaimana menyederhanakan proses belajar sehingga memudahkan belajar peserta didik. Prinsipnya adalah bahwa sugesti dapat dan pasti mempengaruhi hasil situasi belajar, setiap detail apapun memberikan sugesti positif atau negatif. Dan melalui pembelajaran quantum inilah peserta didik akan diajak belajar dalam suasana yang lebih nyaman dan menyenangkan, sehingga peserta didik akan lebih bebas menemukan berbagai pengalaman baru dalam belajarnya.

Istanti (2015) berpendapat bahan ajar adalah modul yang dirancang untuk membantu peserta didik menguasai tujuan belajar dan sebagai sarana belajar siswa secara mandiri sesuai kecepatan masing-masing. Melalui penggunaan modul, peserta didik memiliki efektivitas waktu belajar karena tidak harus menunggu temannya yang kecepatannya beragam. Jika sudah selesai, peserta didik dapat lanjut ke unit berikutnya.

Hal ini dibuktikan dengan hasil penelitian yang diungkapkan oleh beberapa peneliti. Seperti hasil penelitian Hidayati (2015) membuktikan bahwa produk modul yang dihasilkan layak digunakan sebagai media pembelajaran. Hal ini berdasarkan pada skor yang diberikan oleh dosen ahli materi 44,5\% dan dosen ahli media $46,7 \%$ respon peserta didik $91 \%$ (sangat tinggi).

Penelitian Estuwardani dan Mustadi (2015) yang membuktikan bahwa modul tematik-integratif dapat meningkatkan karakter tangggung jawab dan disiplin peserta didik. Hal ini dikarenakan terdapat perbedaan yang signifikan terhadap peningkatan karakter tanggung jawab dan disiplin pada kelas eksperimen yang menggunakan bahan ajar hasil pengembangan dan kelas kontrol yang menggunakan bahan ajar dari pemerintah. Karakter siswa dalam aspek tanggung jawab pada kelas eksperimen persentase peningkatan sebesar 88\%, sedangkan pada kelas kontrol sebesar $63,97 \%$. Karakter siswa dalam aspek disiplin pada kelas eksperimen persentase peningkatan sebesar $89 \%$, sedangkan pada kelas kontrol sebesar $63,60 \%$.

Mengacu pada hasil-hasil penelitian di atas, maka peneliti mengadakan pengembangan bahan ajar modul berbasis quantum learning tema ekosistem untuk kelas $\mathrm{V}$ sekolah dasar. Model pembelajaran quantum akan disajikan dalam sebuah modul karena telah dijelaskan diatas bahwa penggunaan modul belum tersedia karena belum adanya yang mengembangkan modul sebagai bahan ajar pendamping. Penggunaan modul dalam proses pembelajaran telah terbukti mampu meningkatkan kualitas pembelajaran.

\section{METODE PENELITIAN}

Penelitian ini mengacu pada metode penelitian dan pengembangan atau Research and Development $(R \& D)$ Borg and Gall (dalam Sugiyono: 2009). Subjek penelitian adalah siswa kelas V SDN Lamper Tengah 02 Semarang. Dalam penelitian ini dilakukan uji coba modul, yaitu uji coba produk dengan jumlah 12 siswa dari jumlah keseluruhan 42 siswa.

Peneliti telah menggunakan metode pengumpulan data berupa observasi, wawancara (interview), angket (kuisioner) dan studi dokumenter untuk memperoleh data penelitian.

\section{HASIL PENELITIAN}

Produk akhir penelitian pengembangan ini adalah Modul Tematik berbasis Quantum Learning pada tema Ekosistem. Penelitian dan pengembangan Modul Tematik ini dilaksanakan melalui sembilan tahap penelitian Research and Development, hasil adaptasi dan modifikasi dari tahapan penelitian pengembangan Borg dan Gall (dalam sugiyono:2009). 
Penelitian dan pengembangan Modul tematik diawali dengan mengumpulkan informasi awal mengenai situasi dan kondisi di 3 SD, yaitu SDN Lamper Tengah 01 Semarang, SDN Lamper Tengah 02 Semarang, dan SDN Jomblang 01 Semarang melalui kegiatan penelitian pendahuluan. Informasi dan data-data yang telah didapatkan dari hasil penelitian pendahuluan, diolah dan dianalisis terlebih dahulu. Sehingga, dari hasil analisis data tersebut diperoleh suatu kesimpulan bahwa pengembangan Modul Tematik sangat diperlukan guna mengatasi masalah pembelajaran tematik di kelas V SDN Lamper Tengah 02 Semarang yakni tidak tersedianya penunjang bahan ajar yang relevan dengan kurikulum yang diterapkan.

Hasil analisis data penelitian pendahuluan, selanjutnya digunakan untuk menyusun rencana penelitian dan pengembangan Modul Tematik. Setelah rencana penelitian dan pengembangan Modul Tematik selesai disusun, peneliti melakukan pengembangan draf awal produk Modul Tematik. Pengembangan draf awal Modul Tematik dilaksanakan sesuai dengan prosedur pengembangan bahan ajar modul yang dikemukakan oleh Daryanto (2013) yaitu; 1) melakukan analisis untuk mengidentifikasi masalah dan kebutuhan, 2) dilanjutkan dengan membuat perencanaan pengembangan dengan merancang konsep desain dan menyusun materi dalam buram, 3) konsep desain produk dan materi Modul Tematik yang telah selesai disusun selanjutnya disatukan, sehingga menghasilkan prototype Modul Tematik yang siap cetak, 4) prototype produk yang sudah dicetak diserahkan kepada ahli materi dan ahli media untuk divalidasi dan dievaluasi, 5) sesuai dengan saran dan masukan dari para ahli, maka produk Modul Tematik akan direvisi. Setelah prototype produk Modul Tematik selesai diperbaiki dan disempurnakan, proses penelitian dilanjutkan ke tahap berikutnya yaitu uji coba lapangan awal.

Produk Modul Tematik yang dihasilkan dari penelitian pengembangan ini telah sesuai dengan prinsip-prinsip pembelajaran Quantum Learning yang dipaparkan oleh DePoter (2012) antara lain strategi TANDUR dirancang untuk meningkatkan aktivitas siswa dengan pemberian pengalaman belajar melalui pengamatan, penyelidikan, maupun diskusi atas pemasalahan yang ditemukan dalam kehidupan sehari-hari. Pengalaman belajar tersebut dikemas dalam skenario pembelajaran yang menyenangkan. TANDUR adalah kependekan dari Tumbuhkan, Alami, Namai, Demonstrasikan, Ulangi, dan Rayakan yang merupakan kerangka rancangan pembelajaran quantum learning.

\section{Kelayakan Produk}

Kelayakan produk Modul Tematik ini diuji melalui tiga tahap uji, yaitu; a) tahap validasi dan evaluasi ahli materi, b) tahap validasi dan evaluasi ahli modul, c) tahap uji coba lapangan awal.

a. Validasi Ahli Materi

Validasi oleh ahli materi ditujukan untuk mengetahui kualitas materi dalam Modul Tematik. Ahli materi memberikan penilaian terhadap beberapa aspek diantaranya aspek pendekatan penulisan, aspek kebenaran konsep, aspek kedalaman dan keluasan konsep, aspek kebahasan, aspek kualitas kelengkapan, aspek penyajian, aspek penampilan fisik. Berdasarkan validasi materi tahap 1 diperoleh hasil $61,7 \%$ dengan kategori "baik", dan validasi tahap 2 diperoleh hasil nilai $82,7 \%$. Hal ini menunjukan bahwa modul tematik berbasis Quantum Learning termasuk dalam katagori "baik" dan "layak digunakan"

Tabel 1

Hasil penilaian ahli materi tahap 1 Modul Tematik berbasis Quantum Learning

\begin{tabular}{|c|c|c|c|c|}
\hline No & Indikator & $\begin{array}{l}\text { Jumlah } \\
\text { Skor }\end{array}$ & $\begin{array}{l}\text { Skor } \\
\text { Ideal }\end{array}$ & Persentase \\
\hline 1 & $\begin{array}{l}\text { Pendekatan } \\
\text { Penulisan }\end{array}$ & 17 & 30 & $\frac{17}{30} \times 10096=56,696$ \\
\hline 2 & $\begin{array}{l}\text { Kebenaran } \\
\text { Konsep }\end{array}$ & 19 & 30 & $\frac{19}{30} \times 10096=63,396$ \\
\hline 3 & $\begin{array}{l}\text { Kedalaman } \\
\text { dan } \\
\text { Keluasan } \\
\text { Konsep }\end{array}$ & 17 & 30 & $\frac{17}{30} \times 100 \% b=56,6 \%$ \\
\hline 4 & Kebahasaan & 30 & 50 & $\frac{30}{50} \times 100 \% b=60,0 \% 6$ \\
\hline 5 & $\begin{array}{l}\text { Kelengka- } \\
\text { pan }\end{array}$ & 13 & 20 & $\frac{13}{20} \times 100 \% 6=65,0 \% 6$ \\
\hline 6 & Penyajian & 17 & 30 & $\frac{17}{30} \times 100 \% 6=56,6 \%$ \\
\hline 7 & $\begin{array}{l}\text { Penampilan } \\
\text { Fisik }\end{array}$ & 66 & 100 & $\frac{66}{100} \times 10096=66,096$ \\
\hline & Jumlah & 179 & 290 & $\frac{179}{290} \times 100 \%=61,7 \%$ \\
\hline \multicolumn{4}{|c|}{ Kategori } & Baik \\
\hline
\end{tabular}


Tabel 2

Hasil penilaian ahli materi tahap 2 Modul Tematik berbasis Quantum Learning

\begin{tabular}{|c|c|c|c|c|}
\hline No & Indikator & $\begin{array}{c}\text { Jml } \\
\text { Skor }\end{array}$ & $\begin{array}{l}\text { Skor } \\
\text { Ideal }\end{array}$ & Persentase \\
\hline 1 & $\begin{array}{l}\text { Pendekatan } \\
\text { Penulisan }\end{array}$ & 25 & 30 & $\frac{25}{30} \times 100 \%=83,3 \%$ \\
\hline 2 & $\begin{array}{l}\text { Kebenaran } \\
\text { Konsep }\end{array}$ & 24 & 30 & $\frac{24}{30} \times 100 \%=80,0 \%$ \\
\hline 3 & $\begin{array}{l}\text { Kedalaman } \\
\text { dan } \\
\text { Keluasan } \\
\text { Konsep }\end{array}$ & 24 & 30 & $\frac{24}{30} \times 100 \%=80,0 \%$ \\
\hline 4 & Kebahasaan & 43 & 50 & $\frac{43}{50} \times 100 \%=86,0 \%$ \\
\hline 5 & $\begin{array}{l}\text { Kelengka- } \\
\text { pan }\end{array}$ & 17 & 20 & $\frac{17}{20} \times 100 \%=85,0 \%$ \\
\hline 6 & Penyajian & 25 & 30 & $\frac{25}{30} \times 100 \%=83,3 \%$ \\
\hline 7 & $\begin{array}{l}\text { Penampilan } \\
\text { Fisik }\end{array}$ & 82 & 100 & $\frac{82}{100} \times 100 \% 6=82,0 \%$ \\
\hline & Jumlah & 240 & 290 & $\frac{240}{290} x 100 \%=82,7 \%$ \\
\hline \multicolumn{4}{|c|}{ Kategori } & Sangat Baik \\
\hline
\end{tabular}

b. Validasi Ahli Modul

Uji kelayakan terhadap aspek modul dalam Modul Tematik, ditujukan untuk mengetahui kualitas dan kelayakan Modul Tematik sebagai penunjang bahan ajar siswa. Uji kelayakan ini dilakukan melalui validasi dan evaluasi oleh ahli media terkait aspek cover modul, fisik modul, kualitas grafis, isi modul.

Berdasarkan validasi modul tahap 1 diperoleh hasil 75,00\% dengan kategori "baik", dan validasi tahap 2 diperoleh hasil nilai 94,3\%. Hal ini menunjukan bahwa modul tematik berbasis Quantum Learning termasuk dalam katagori "sangat baik" dan "layak digunakan".

Tabel 3

Hasil penilaian ahli modul tahap 1

Modul Tematik berbasis Quantum Learning

\begin{tabular}{|c|l|c|c|c|}
\hline No & Indikator & $\begin{array}{c}\text { Jml } \\
\text { Skor }\end{array}$ & $\begin{array}{c}\text { Skor } \\
\text { Ideal }\end{array}$ & Persentase \\
\hline 1 & $\begin{array}{l}\text { Cover } \\
\text { Modul }\end{array}$ & 35 & 45 & $\frac{35}{45} \times 100 \% 6=77,7 \% 6$ \\
\hline 2 & $\begin{array}{l}\text { Fisik } \\
\text { Modul }\end{array}$ & 33 & 45 & $\frac{33}{45} \times 100 \% 6=73,3 \% 6$ \\
\hline 3 & $\begin{array}{l}\text { Kualitas } \\
\text { Grafis }\end{array}$ & 23 & 30 & $\frac{23}{30} \times 100 \% 6=76,6 \% 6$ \\
\hline
\end{tabular}

\begin{tabular}{|c|c|c|c|c|}
\hline 4 & Isi Modul & 29 & 40 & $\frac{29}{40} \times 100 \% 6=72,5 \% 6$ \\
\hline Jumlah & 120 & 160 & $\frac{120}{160} \times 100 \% 6=75,0 \% 6$ \\
\hline \multicolumn{3}{|c|}{ Kategori } & & Baik \\
\hline
\end{tabular}

Tabel 4

Hasil penilaian ahli modul tahap 2

Modul Tematik berbasis Quantum Learning

\begin{tabular}{|c|c|c|c|c|}
\hline No & Indikator & $\begin{array}{c}\text { Jml } \\
\text { Skor }\end{array}$ & $\begin{array}{l}\text { Skor } \\
\text { Ideal }\end{array}$ & Persentase \\
\hline 1 & $\begin{array}{l}\text { Cover } \\
\text { Modul }\end{array}$ & 42 & 45 & $\frac{42}{45} \times 10096=93,3 \% 6$ \\
\hline 2 & $\begin{array}{l}\text { Fisik } \\
\text { Modul }\end{array}$ & 42 & 45 & $\frac{42}{45} \times 100 \% 6=93,3 \% 6$ \\
\hline 3 & $\begin{array}{l}\text { Kualitas } \\
\text { Grafis }\end{array}$ & 28 & 30 & $\frac{28}{30} \times 100 \% 6=93,3 \% 6$ \\
\hline 4 & Isi Modul & 39 & 40 & $\frac{39}{40} \times 100 \% 6=97,5 \% 6$ \\
\hline & Jumlah & 151 & 160 & $\frac{151}{160} \times 100 \%=94,3 \%$ \\
\hline \multicolumn{4}{|c|}{ Kategori } & Sangat Baik \\
\hline
\end{tabular}

Revisi

Revisi produk Modul Tematik dilakukan sesuai saran dan masukan dari ahli materi dan ahli media. Berikut hasil revisi produk Modul Tematik yang telah dilakukan:

1. Hasil Revisi Cover Modul

Perbaikan: Semula cover ambil dari gambar yang ada di internet, kemudian diganti dengan mendesain cover sendiri.

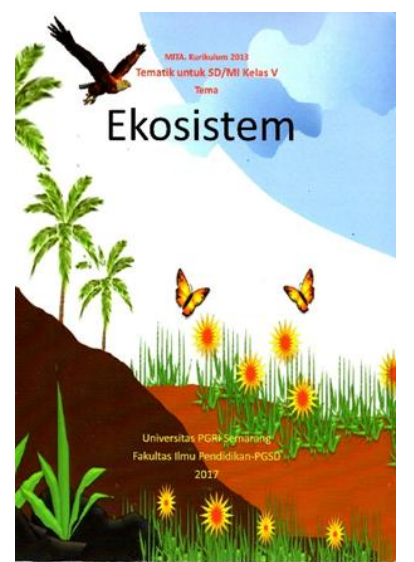

Gambar 1

Sebelum Revisi 


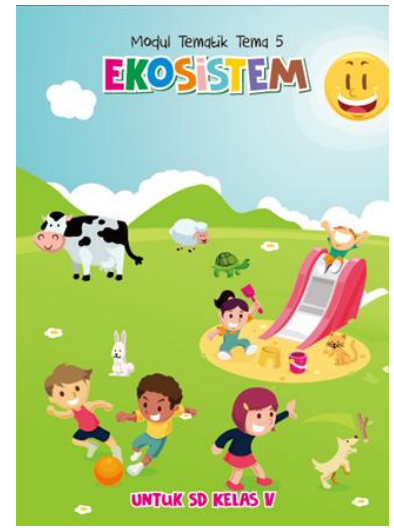

Gambar 2

\section{Sesudah Revisi}

2. Hasil Revisi Redaksi Modul

Perbaikan: Semula huruf yang digunakan pada redaksi modul fontnya terlalu kecil, terkesan seperti makalah, tidak tuliskan nama penyunting modul, dan juga tidak terdapat logo universitas, kemudian diganti dengan ukuran font yang sesuai, di tuliskan nama penyunting modul, dan diberi logo universitas.

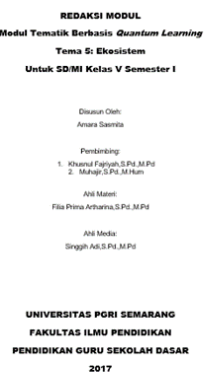

Gambar 3 Sebelum Revisi

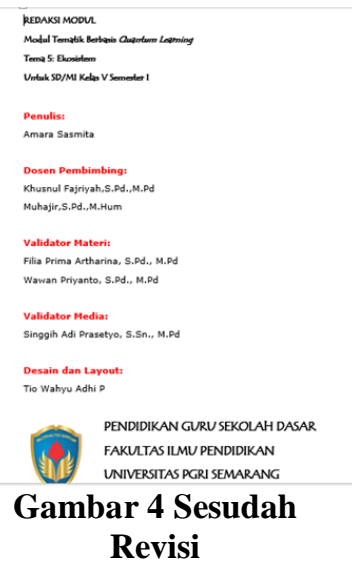

3. Hasil Revisi Kata Pengantar Perbaikan: Semula terdapat kata "selaku", kemudian dihapus.

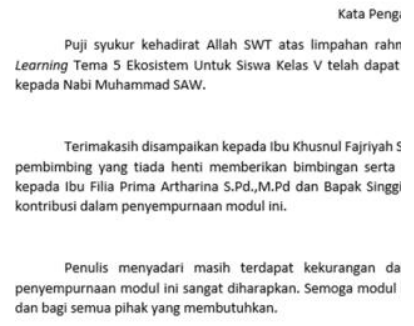

Gambar 5

Sebelum Revisi

Kata Penga

Puji syukur kehadirat Allah SWT atas limp Modul Berbasis Quantum Learning Tema 5 Ekos
diselesaikan. Shalawat dan salam semoga terlimp

Terimakasih disampaikan kepada Ibu Khu Muhajir, S.Pd., M.Hum| dosen pembimbing yan serta motivasi kepada penulis. Terimakasih juga Singgin Adi Prasetyo S.Sn., M.Pd validator media modul ini.

Penulis menyadari masih terdapat kekura dan saran terhadap penyempurnaan modul ini : $\mathrm{V}$ kh membutuhkan.

\section{Gambar 6 \\ Sesudah Revisi}

\section{Uji Coba Lapangan Awal}

Tabel 6. Hasil uji coba lapangan awal

\begin{tabular}{|l|l|c|}
\hline No & Nama Lengkap & Nilai \\
\hline 1 & AN & 78,0 \\
\hline 2 & AR & 88,0 \\
\hline 3 & DA & 78,0 \\
\hline 4 & DH & 80,0 \\
\hline 5 & FH & 82,0 \\
\hline 6 & IT & 90,0 \\
\hline 7 & IP & 80,0 \\
\hline 8 & M & 80,0 \\
\hline 9 & R & 80,0 \\
\hline 10 & RS & 82,0 \\
\hline 11 & ZR & 80,0 \\
\hline 12 & DS & 80,0 \\
\hline & & 978 \\
\hline
\end{tabular}

Berdasarkan tabel 6 di atas dapat diketahui bahwa rata-rata nilai hasil belajar siswa sebesar 81,5 . Nilai tersebut diperoleh dari 
post test yang diberikan setelah penggunaan modul berbasis quantum learning tema ekosistem. Dengan demikian modul yang dikembangkan terbukti dapat menunjang pencapaian hasil belajar pada tema ekosistem dengan baik.

\section{SIMPULAN}

Berdasarkan pembahasan hasil penelitian dan pengembangan bahan ajar Modul Tematik berbasis Quantum Learning yang telah dipaparkan sebelumnya, maka dapat disimpulkan bahwa produk Modul Tematik yang dikembangkan telah layak dan dapat digunakan sebagai penunjang bahan ajar siswa kelas V SDN Lamper Tengah 02 Semarang.

Validasi materi tahap 1 diperoleh hasil $61,7 \%$ dengan kategori "baik", dan validasi tahap 2 diperoleh hasil nilai $82,7 \%$. Hal ini menunjukan bahwa modul tematik berbasis Quantum Learning termasuk dalam katagori "baik" dan "layak digunakan". Validasi modul tahap 1 diperoleh hasil 75,00\% dengan kategori "baik", dan validasi tahap 2 diperoleh hasil nilai $94,3 \%$. Hal ini menunjukan bahwa modul tematik berbasis Quantum Learning termasuk dalam katagori "sangat baik" dan "layak digunakan". Hasil uji coba lapangan utama memperlihatkan rata-rata nilai siswa sebesar 81,5 .

\section{DAFTAR PUSTAKA}

Asrori, S. 2013. Penerapan Quantum Learning Untuk Meningkatkan Aktivitas Belajar Siswa Pada Mata Pelajaran PKn Di Kelas V SD Negeri Kembangjatitengan 2 Kabupaten Sleman. Kalam Cendekia PGSD Kebumen, 2(1).

Daryanto. 2013. Menyusun Modul, Bahan Ajar Untuk Persiapan Guru Dalam Mengajar. Yogyakarta: Gava Media.

Estuwardani dan Mustadi, Ali. 2015. Pengembangan Bahan Ajar Modul Tematik-Integratif Dalam Peningkatan Karakter Peserta Didik Kelas 1 Sekolah Dasar. Jurnal Pendidikan Karakter 2.

Hamdani. 2010. Strategi Belajar Mengajar. Bandung: Pustaka Setia.

Hidayatama, Nur. 2016. Pengembangan Bahan Ajar Mengacu Kurikulum 2013 Subtema Indahnya Budaya Indonesia Untuk Siswa
Kelas IV Sekolah Dasar. Skripsi. Universitas Sanata Dharma. Yogyakarta.

Hidayati, Annisa Nurul. 2015. Pengembangan Modul Quantum Learning Berbasis Islam Sains Dalam Pembelajaran IPA Kelas V Di Madrasah Ibtidaiyah. Tesis. UIN Sunan Kalijaga.Yogyakarta.

Istanti, Vanti. 2015. Pengembangan Modul Ilmu Pengetahuan Alam Bagi Siswa Kelas IV Sekolah Dasar. E-Jurnal Skripsi Mahasiswa TP 4.

Kosasih, N., dan Sumarna, Dede. 2013. Pembelajaran Quantum dan Optimalisasi Kecerdasan. Bandung: Alfabeta.

Mandacahyanti, H.R. 2016. Pengembangan Modul Pembelajaran Tematik Kelas III Sekolah Dasar. Skripsi. Universitas PGRI Yogyakarta.

Nasution. 2017. Berbagai Pendekatan dalam Proses Belajar\&Mengajar. Bandung: Bumi Aksara.

Ningrum, A.P., Lesmono, A.D., dan Bachtiar, R.W. 2017. Pengembangan Bahan Ajar Berupa Modul Berbasis Quantum Teaching Pada Pembelajaran Fisika Di SMA. Jurnal Pembelajaran Fisika 5 (4).

Novitasari, E., Masykuri, M., dan Aminah, N. S. 2016. Pengembangan Modul Pembelajaran IPA Terpadu Berbasis Inkuiri Terbimbing Tema Matahari Sebagai Sumber Energi Alternatif di Kelas VII SMP/MTs. Inkuiri, 5 (1): 112121.

Nugraha, Aldila Wanda. 2016. Analisis Kelayakan Buku Ajar Siswa SD Kelas V Tema Ekosistem dan Lingkungan Sahabat Kita Ditinjau Dari Aspek Science Literacy. STKIP PGRI Tulungagung 1 (02).

Siswoyo, A.A., dan Retno, A.Y.W. 2016. Pengembangan Perangkat Pembelajaran Tematik Berbasis Quantum Learning Berdasarkan Pendekatan Saintifik. Widyagogik Universitas Trunojoyo Madura 1 (1). 
Sugiyono. 2009. Metode Penelitian Pendidikan (Pendekatan kuantitatif, Kualitatif, dan $R \& D)$. Bandung: Alfabeta.

Trimantoto, A. S. 2016. Pengembangan Modul Pembelajaran Tematik "Merawat Hewan dan Tumbuhan" Tema 7 Untuk Siswa Kelas 2 SD. E-Jurnal Skripsi Mahasiswa TP, 5(6): 212-225.
Zafira, H., dan Artharina, F.P. 2017. Pengembangan Media Wayang Pada Tema Indahnya Negeri Sebagai Pendukung Scientific Approach Kelas IV Sekolah Dasar. Refleksi Edukatika, 8 (1): 9-15. 